\title{
The Impact of Cognitive Biases on Organizational Effectiveness
}

\author{
Ramalakshmi V. ${ }^{1}$, Haritha P. M. ${ }^{2}$, Hamim Akif K. ${ }^{3}$, Hari Krishnan V. ${ }^{4}$ \\ \{rama.krupanidhi@gmail.com ${ }^{1}$, harithamanoharan96@gmail.com ${ }^{2}$, \\ hamimakif96@gmail.com ${ }^{3}$, harikrishnanvchandran@gmail.com $\left.{ }^{4}\right\}$ \\ Krupanidhi Group of Institutions, Bangalore1
}

\begin{abstract}
In the present competitive market situation, organizational effectiveness driven by effective decision making is a must. But biases hamper the final decision at every level of decision making by the managers. In view of the above scenario, the present study tries to investigate the associations existing between cognitive biases, effective decisionmaking process and organizational effectiveness. These associations are expected to reflect the problem zones for which the study will attempt to provide statistically relevant resolutions. A questionnaire survey was performed for data collection from manufacturing and service industries in Kerala. The responses were analysed with SPSS and AMOS tools along with a RIDIT approach for prioritization of the dimensions. The path model, which has been developed using AMOS (ver 20) to analyse the relationships, shows that the relationship of all the three cognitive biases on effective decision making have a significant influence. Further the study also concludes with a priority ranking of the cognitive biases' dimensions, which is recommended to be focussed by the decision makers for effective decision making facilitating organizational effectiveness.
\end{abstract}

Keywords: Cognitive biases, jumping to conclusions, Belief Inflexibility, External Attribution, Attention for threat, Decision making, Organizational effectiveness

\section{Introduction}

Many businesses have experienced problems and failures due to poor decisions taken by their leaders. Reasons for these failures lie in the fact that they are subject to cognitive biases and beliefs that constantly misrepresent the judgement when making decisions. Managers are usually making ample strategic, tactical and operational decisions. Making better decisions is a big challenge for the executives, managers, staffs and other sponsors. To improve organization's effectiveness, managers should have the ability to overcome these cognitive biases. In the highly competitive manufacturing industry, decision making becomes one of the most important elements for gaining a competitive advantage in the marketplace. Manufacturing industry has gone through many changes since its inception because technology initiates most changes in manufacturing [1]. Most of the manufacturers transformed their business model due to new technology/IT developments. Apart from technology, distribution techniques, workforce changes and the presidential administration will also impact the industry. Manufacturers have a lot to consider when deciding how to conduct business. It is very difficult to adapt fast, to these changes from technological to workforce. Any newly executed operational process or 
technology can bring countless advances to a company, but must be strategically applied to succeed.

Cognitive biases in decision making include a broad variety of nonconformities [2]. Many decision-making biases have been recognized in the literature. New biases are identified by cognitive and social psychology researchers [2]. Managers are clever enough to make many quick and efficient decisions relying on intellectual plans or short cuts. These short cuts allow them to come up with judgments which are "good enough" and, often, correct. These short cuts can lead the managers to expectable cognitive biases. This paper highlights some of the most common cognitive short cuts and resulting biases and their impact on decision making. In another study it was argued that managers concentrate on organization's strategic objectives since amount of information impact the value of decisions [3]. Also, managers take the guidance of their colleagues while making decisions. Considering the above discussed facts, the present study makes an attempt to investigate the relationship existing between cognitive biases, effective decision-making process and overall organizational effectiveness. This study will explore the factors that is considered by the executives while taking decisions towards organization's effectiveness. Further, the study proposes the precedence of the cognitive biases dimensions for effective decision making by the managers.

\section{Review of literature}

\subsection{Organizational effectiveness}

Organizational effectiveness is one of the most complex and least tackled problems in the study of social organizations [4]. The idea of organizational effectiveness is normally used to mention goal-achievement. Conventionally, in the study of industrial organizations, effectiveness has been observed mainly in terms of productivity. Organizational effectiveness was viewed as the combination of organizational productivity, net profit, the extent to which the organization accomplishes its various missions and the success of the organization in maintaining or expanding itself [5]. Other variables that have been used in various contexts as criteria of effectiveness include "morale," commitment to the organization, personnel turnover and absenteeism, and member satisfactions [6].

Organizational effectiveness is multidimensional and is manifested in various perspectives [7]. It is experimented as a significant topic in the knowledge of organisation. As such, it has captivated a growing amount of research interest [7]. Various theoretical frameworks and guidelines for formulating criteria were developed by organizational effectiveness. The performance of organisations indifferent settings was measured by this. Organizational effectiveness is converting inputs into valuable outputs effectively and efficiently [8]. To achieve organizational effectiveness competitive advantage, adaptability, optimum utilization of resources and to produce quality products effective decision making is very essential. Organizational effectiveness is the ability of the organization to achieve expected goals and objectives of the sponsors at correct time.

Organizational effectiveness was defined as "the maximization of return to the organization by all means" [9], "the degree of congruence between organizational goals and observable outcomes" [10] and "the capacity of an organization to activate its centres of authority, for 
action, manufacturing and adaptation" [11]. Effective firms are those who generally tend to provide greater and adapt more without difficulty to environmental and internal issues than do different similar firms. Organizational effectiveness is the capability to achieve strategic and operational goals of the organization [12]. It is based on four approaches: the goal approach, the systems approach, the competing values approach, and the strategic constituency approach [13]. These are effective methods which are depending upon the type of situation to arise. Researchers discussed about several aspects of organizational effectiveness [14]. Accomplishing organizational effectiveness is a conclusive motive to be involved by any institution that needs massive push to enhance employees' task proficiency, accountability, and support essential inspiration to perform well in troublesome situations [15]. Hence efforts were taken to enhance organizational performance which teach positive organizational ideas like faith, engagement and psychological capital.

\subsection{Decision Making}

Managers and executives have the responsibility of making better decisions to improve the productivity of the organization, their employees and other stakeholders. About decisions making models the literature offers plenty of references. Quantitative and qualitative methods can help decision-makers to construct and elucidate tough problems [16]. Researchers analysed about the quality of decision making. Incorrect decisions made by wrong people will affect the organization very badly [17]. Team involvement is very much essential to create and assess different alternatives of problems solving and effective decision making [18]. Minority power and time pressure can be the barriers of independent decisions [19]. Success of the organization depends on the quality and rapid decision making [20]. Identifying the goals, analysing the substitutes for finding the solutions and assessing and matching the values and interest determine the quality of decision making [21]. To analyse and differentiate between alternatives, risk analyses is required [22]. Effective decisions depend upon the utilization of quantitative and qualitative criteria $[23,24]$.

Surveys provide sensible and realistic information to managers and help them to take better decisions [25]. McKinsey survey provide the information regarding the successful strategic decisions of companies. It revealed about where the companies went wrong [25]. Effective decision-making influences the individual performance [26]. Effective decision-making influences organization's effectiveness [27]. People have diverse decision-making styles differ with the respect to the amount of information people use, the number of alternatives they consider, and the extent to which they attempt to integrate and coordinate multiple sources of input [28]. Decision-making quality is described as the accuracy and exactness of decisions [29]. Decision quality may improve or reduce when information quality and processing improve or reduce. Decision-makers can make effective decisions if they know about the associations between problem variables thoroughly [29]. Johnson and McCarthy developed a trade-off decision-making model for any given product to determine the level of remanufacturing that is more profitable than dismantling under the extended producer responsibility legislation setting [30].

\subsection{Impact of decision making on Organizational effectiveness}

Blenko et. al, emphasized on decision making effectiveness and told that wrong decisions taken by people impact the organization very badly [17]. Druker explained about the importance of 
involvement of teams in decision making process [31]. Generating and evaluating different alternatives of resolving anomalies are effectual for the organization [32]. Minority domination or time pressure disturb the decision-making process [33]. The success or failure of the organization depends upon the speed and quality of decision making [34]. Identifying the goals, deciding the alternatives for resolving the issues, assessing and harmonizing the standards and attention are vital for effective decision making [35]. Risk and hazard analyses are essential to distinguish among substitutes [22]. Quantitative and qualitative measures need to be used properly for making efficient decisions [23]. Managers need to know the optimum utilization of the data for decision making. Managers should be rational, creative and balanced while taking decisions [36]. Reasonable information about decision making and foundations for enlightening the responsibility will be obtained through surveys [25]. Effective decision-making influence performance of the individual [37]. There exists a positive and significant relationship between effective decision making and organization's effectiveness [27].

The assumption being that organization's effectiveness is more likely to be influenced by effective decision-making process leads to the following hypothesis to be tested.

\section{H1: Effective decision-making process has significant impact on organizational effectiveness}

\subsection{Cognitive Biases}

Heuristics and biases play an important role in decision making research. Cognitive biases were addressed in many behavioural researches. They lead judgements and decisions which were deviated from normative philosophies [38]. These biases were used as shortcuts for strategic decision making [39]. It is a systematic difference between the "correct" response given by a formal normative rule, and the decisionmaker's real response [40]. The term cognitive bias was familiarized by Amos Tversky and Daniel Kahneman. After that large number of biases in human judgment and decision making was identified by behavioural decision researchers. These biases are deviated from a normative rule of probability theory. Biases and errors in decision making can be corrected by risk analysts. Kahneman et al., provided huge literature on cognitive biases and excellent compilations of papers [41]. Extensive range of deviations from rational judgment and decisions included in cognitive biases which affect decision making [2]. According to them cognitive plans or short cuts are useful to make many quick and efficient decisions instinctively. Good and correct decisions can be made by these short cuts. But these shortcuts also affect people with probable cognitive biases.

Cognitive biases are persistent constituent of effective decision making. To achieve the goals of the organization, managers need to understand the impact of biases on decision making processes. Importance of cognitive biases are considered in strategic decision making. Nevertheless, little effort has been made to integrate cognitive biases with various modes of decision making beyond the early attempt by Lyles and Thomas to study biases in problem formulation [42]. According to researchers, few cognitive biases are `strong tendencies' that are present in various situations [43]. The "Oxford Dictionary On-Line" defines bias as a "cause to feel or show inclination or prejudice against someone or something". According to "Business Dictionary On-Line", cognitive bias is the common propensity to attain and process data by clarifying it through one's own likes, aversions, and practices. Group bias is directly related to group-think, which is "the practice of thinking or making decisions as a group, resulting in typically in unchallenged, poor-quality decision making". "Cognitive biases are cognitions or 
mental behaviours that prejudice decision quality in a significant number of decisions for a significant number of people; they are inherent in human reasoning" [44]. Cognitive biases are also called as decision biases or judgement biases. Cognitive biases are expectable deviations from rationality. According to Loewenstein (1996), the role of cleverness and specific differences in cognitive bias research has been largely overlooked, as have the effects of intuitive or 'hot' factors on decision-making [45]. The questionnaire of the study specifically aims to measure few cognitive biases namely jumping to conclusions bias, belief inflexibility bias, selective attention for threat bias and external attribution bias. Knowing which biases are active and choosing the suitable de-biasing techniques for eliminating those biases is very important to improve organizational effectiveness.

\subsubsection{Jumping to conclusions bias}

It is referred to as the inference-observation confusion (Hamilton, Cheryl 2011) [46]. According to him, "It is a psychological term referring to a communication difficulty where one, judges or decides something without having all the proofs; to reach unjustified deductions" [46]. Jumping to conclusion bias involves decisions which are not having adequate proof, not to be sure that decision maker is right. This bias can lead to bad or rash decisions. Jumping to conclusions is a form of cognitive distortion [47]. Individuals make negative statements if assumptions are not fully supported by the evidences [49]. Jumping to conclusions lead to incorrect decoding of incoming messages [46]. Managers will be making an intended risk because of this bias. Evaluators may jump to conclusions because of incorrect interpretation and it leads to a costly hiring fault. Inferences can be explored by asking explanations [46]. To avoid jumping to conclusions bias, managers should know what context a word is being utilized. In the view of Jerome Groopman, "most incorrect diagnoses are due to physicians' misconceptions of their patients, not technical mistakes like a faulty lab test" [50].

The assumption being that effective decision-making process is more likely to be influenced by jumping to conclusions bias leads to the following hypothesis to be tested.

$\mathrm{H}_{2 a}$ : Jumping to conclusions bias has significant impact on effective decision-making process.

\subsubsection{Belief Inflexibility bias}

Belief inflexibility (BI) has been considered as a crucial factor for delusional conviction, but less is known about other dimensions of delusional beliefs. Question has been raised regarding the extent to which BI distinguishes delusions from strongly held (non-deluded) personally meaningful beliefs [51]. Belief inflexibility is constantly related with the maintenance of misunderstandings. Measuring belief inflexibility in routine clinical practice will inform psychological interferences for patients with persistent misunderstandings. Interview- and taskbased procedures of belief inflexibility may be used complementarily to enable our understanding of this reasoning bias. The assumption being that effective decision-making process is more likely to be influenced by belief inflexibility bias leads to the following hypothesis to be tested.

$H_{2 b}$ : Belief Inflexibility bias has significant impact on effective decision-making process.

\subsubsection{Attention for Threat bias}


Attentional threat bias (TB), defined as overstated consideration toward aggressive information and stimuli, is assumed to play a dominant role in the maintenance of anxiety complaints [52]. Potentially, concentrating attentional resources toward aggressive inducements contributes to the development of anxious behaviour and eventually clinical weakening [53]. Furthermore, it may confirm anxious opportunities that threat is present, thus supporting nervousness. Attentional bias is the tendency for people's insight to be exaggerated by their frequent thoughts at the time [52]. Attentional biases may enlighten an individual's failure to consider other options, as specific thoughts guide the thoughts in a certain manner [54]. Attentional bias has been related with anxiety and depression [55].

The assumption being that effective decision-making process is more likely to be influenced by attention for threat bias leads to the following hypothesis to be tested.

\section{$H_{2 c}$ : Attention for Threat bias has significant impact on effective decision-making process.}

\subsubsection{External Attribution bias}

A person's behaviour is due to personal factors such as traits, abilities, or feelings or due to situational factors. Research on attribution biases explained why and how people create meaning about others and their own behaviour. It is recognizing how a viewer makes use of records in his/her social surroundings with a purpose to create a causal reason behind activities. Attribution concept additionally provides motives for why specific humans can interpret the identical event in extraordinary ways and what elements make contributions to attribution biases [56]. Attribution bias is a psychological predisposition that mentions to the thoughtful errors made when individuals survey or attempt to discover clarifications for their very own and others' practices [57]. Individuals continually make attributions about the reason for their own and others' practices; however, attributions do not always exactly duplicate realism [58]. Attribution biases were found between the ages of fifty and sixty [59]. Different analysts, which include Harold Kelley and Ed Jones broadened Heider's initial work by methods for perceiving conditions beneath which people are credible to make selective categories of attributions.

The assumption being that effective decision-making process is more likely to be influenced by external attribution bias leads to the following hypothesis to be tested.

H2d: External Attribution bias has significant impact on effective decision-making process. 


\section{Research/Hypothesized Model}

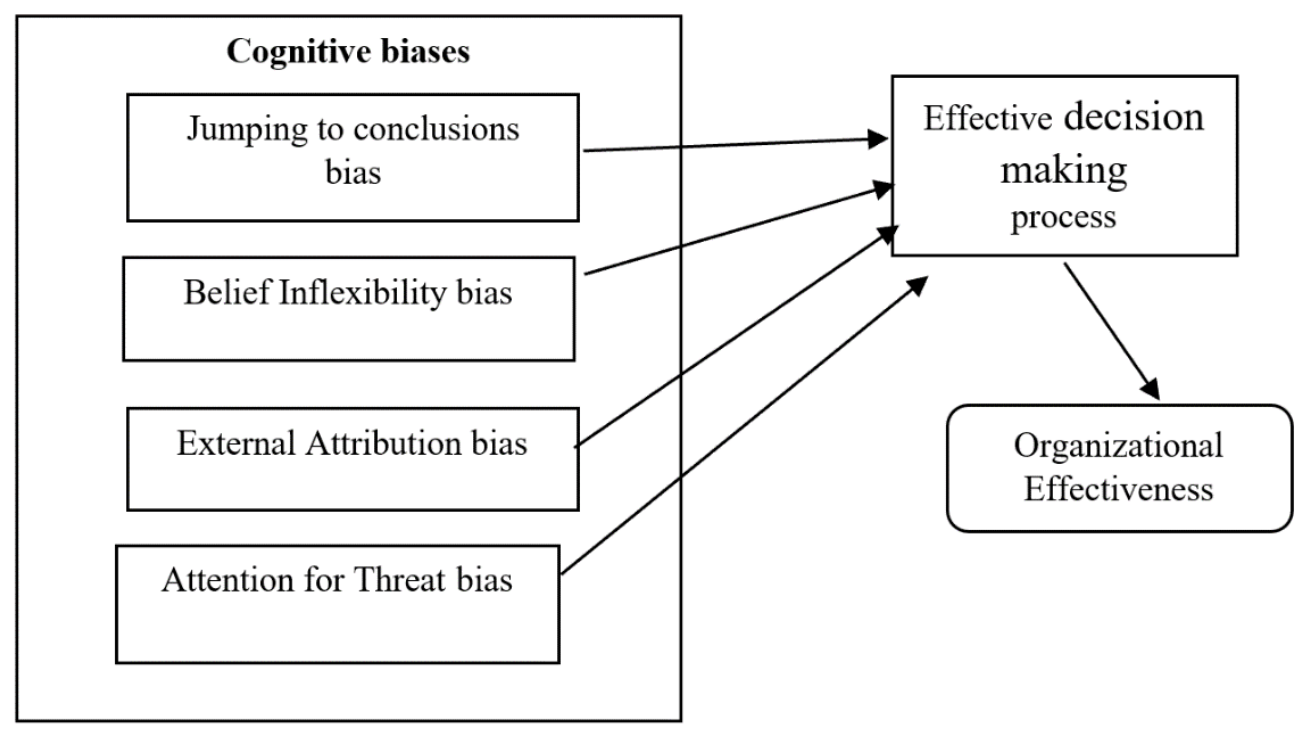

Fig.1 Hypothesized Model

\section{Method}

A structured questionnaire with 7-point Likert scale was prepared for gathering a) primary data for the study and b) questions on the constructs related to cognitive biases, effective decisionmaking process and organizational effectiveness. Four manufacturing units in Kerala were selected using convenient sampling method for the study. Managers of all levels of the four units were explained about the study. After the explanation of the questionnaire, it was circulated to all the managers and responses were collected for further analysis. The questionnaire was distributed to 592 managers. Only 373 complete responses were received with a response rate of 63 per cent. The descriptive statistics of the respondents are shown in Table 1.

\begin{tabular}{|c|c|c|c|c|c|}
\hline & $\mathbf{N}$ & Minimum & Maximum & Mean & Std. Deviation \\
\hline JCB01 & 373 & 1.00 & 7.00 & 4.9196 & 1.93551 \\
\hline JCB02 & 373 & 1.00 & 7.00 & 5.3887 & 1.68854 \\
\hline JCB03 & 373 & 1.00 & 7.00 & 5.1314 & 1.77389 \\
\hline JCB04 & 373 & 1.00 & 7.00 & 5.2493 & 1.71944 \\
\hline JCB05 & 373 & 1.00 & 7.00 & 5.2413 & 1.79627 \\
\hline EDM01 & 373 & 1.00 & 7.00 & 5.0161 & 1.73972 \\
\hline
\end{tabular}




\begin{tabular}{|c|c|c|c|c|c|}
\hline EDM02 & 373 & 1.00 & 7.00 & 4.9920 & 1.79229 \\
\hline EDM03 & 373 & 1.00 & 7.00 & 5.0188 & 1.74201 \\
\hline EDM04 & 373 & 1.00 & 7.00 & 4.7989 & 1.72577 \\
\hline EDM05 & 373 & 1.00 & 7.00 & 5.1233 & 1.57972 \\
\hline EAB01 & 373 & 1.00 & 7.00 & 5.9651 & 1.10540 \\
\hline EAB02 & 373 & 1.00 & 7.00 & 6.2118 & .99497 \\
\hline EAB03 & 373 & 1.00 & 7.00 & 6.0965 & 1.18063 \\
\hline EAB04 & 373 & 1.00 & 7.00 & 6.0295 & 1.14849 \\
\hline EAB05 & 373 & 1.00 & 7.00 & 5.8954 & 1.20363 \\
\hline OE01 & 373 & 1.00 & 7.00 & 5.7668 & 1.23208 \\
\hline OE02 & 373 & 1.00 & 7.00 & 5.7882 & 1.17806 \\
\hline OE03 & 373 & 1.00 & 7.00 & 5.5657 & 1.34568 \\
\hline OE04 & 373 & 1.00 & 7.00 & 5.8579 & 1.27578 \\
\hline OE05 & 373 & 1.00 & 7.00 & 6.0831 & 1.07566 \\
\hline ATB01 & 373 & 1.00 & 7.00 & 5.3083 & 1.49150 \\
\hline ATB02 & 373 & 1.00 & 7.00 & 5.3619 & 1.57102 \\
\hline ATB03 & 373 & 1.00 & 7.00 & 5.4745 & 1.82354 \\
\hline ATB04 & 373 & 1.00 & 7.00 & 5.2922 & 1.71266 \\
\hline Valid N (listwise & 373 & & & & \\
\hline
\end{tabular}

Table 1 Descriptive Statistics

\section{Measures}

\subsection{Cognitive Biases}

The scale which was framed by Van der Gaag, M et.al, (Davos Assessment of the Cognitive Biases Scale (24 items), was used to measure the presence of four cognitive biases listed in the research model [60]. Each item is a statement that was scored on a 7-point Likert scale.

\subsection{Effective decision-making Process}

The scale which was framed by French DJ, West RJ, Elander J, Wilding JM was used to measure the quality and effectiveness of decision-making process [61]. Responses to 7 items of the decision-making questionnaire formed seven independent and internally coherent dimensions according to a principal component analysis. These were labelled: control, thoroughness, instinctiveness, social resistance, hesitancy, perfectionism, and idealism. 


\subsection{Organizational Effectiveness}

To measure organizational effectiveness, 10 items scale was taken from questionnaire developed by Dallas Theological Seminary.

\section{Data Analysis}

\subsection{Reliability Test}

Table 2, shows the reliability test for the data collected for the present study and the result is satisfactory and the values are under the acceptable range [62].

\begin{tabular}{|c|c|}
\hline $\begin{array}{c}\text { Cronbach's } \\
\text { Alpha }\end{array}$ & N of Items \\
\hline .924 & 24 \\
\hline
\end{tabular}

Table: 2 Reliability Statistics

\begin{tabular}{|c|c|c|c|}
\hline SI No & Name of the construct & $\begin{array}{c}\text { Cronbach's Alpha } \\
\text { Value }\end{array}$ & No. of Items \\
\hline 1 & ATB & .889 & 4 \\
\hline 2 & JCB & .874 & 5 \\
\hline 3 & EAB & .842 & 5 \\
\hline 4 & EDM & .900 & 5 \\
\hline 5 & OE & .865 & 5 \\
\hline
\end{tabular}

Table 3: Reliability Statistics for individual variables

The reliability test results show that all the variables have Cronbach's alpha value greater than the recommended threshold of 0.7 and above for going ahead with the analysis. It is found that the alpha value for Effective Decision Making is the highest $(\alpha=0.900)$ followed by Attention for Threats Bias $(\alpha=0.889)$, Jumping to Conclusion Bias $(\alpha=0.874)$, Organizational Effectiveness $(\alpha=0.865)$ and External Attribution Bias $(\alpha=0.842)$. Hence, the validity of the data is confirmed for further analysis. Further, the data set shows an acceptable KMO and Bartlett's value i.e. 0.905 , which is ideal for moving ahead with the factor analysis.

\begin{tabular}{|c|c|c|}
\hline \multicolumn{2}{|c|}{ Kaiser-Meyer-Olkin Measure of Sampling Adequacy. } & .905 \\
\hline \multirow{3}{*}{ Bartlett's Test of Sphericity } & Approx. Chi-Square & 5581.172 \\
\hline & df & 276 \\
\hline & Sig. & .000 \\
\hline
\end{tabular}

Table 4: KMO and Bartlett's Test 
Also, the total variance explained is found to be 68.994, which is acceptable for further analysis. Table 5 below shows the Eigen value and variance explained of the dataset used in the present study.

\begin{tabular}{|c|c|c|c|c|c|c|c|c|c|}
\hline \multirow[t]{2}{*}{ Component } & \multicolumn{3}{|c|}{ Initial Eigenvalues } & \multicolumn{3}{|c|}{$\begin{array}{l}\text { Extraction Sums of } \\
\text { Squared Loadings }\end{array}$} & \multicolumn{3}{|c|}{$\begin{array}{c}\text { Rotation Sums of Squared } \\
\text { Loadings }\end{array}$} \\
\hline & Total & $\begin{array}{c}\% \text { of } \\
\text { Variance }\end{array}$ & $\begin{array}{c}\text { Cumulative } \\
\%\end{array}$ & Total & $\begin{array}{c}\% \text { of } \\
\text { Variance }\end{array}$ & $\begin{array}{c}\text { Cumulative } \\
\%\end{array}$ & Total & $\begin{array}{c}\% \text { of } \\
\text { Variance }\end{array}$ & $\begin{array}{c}\text { Cumulative } \\
\%\end{array}$ \\
\hline EDM & 8.873 & 36.969 & 36.969 & 8.873 & 36.969 & 36.969 & 3.768 & 15.698 & 15.698 \\
\hline $\mathrm{JCB}$ & 2.979 & 12.413 & 49.383 & 2.979 & 12.413 & 49.383 & 3.444 & 14.349 & 30.047 \\
\hline $\mathrm{OE}$ & 1.761 & 7.335 & 56.718 & 1.761 & 7.335 & 56.718 & 3.261 & 13.585 & 43.632 \\
\hline EAB & 1.520 & 6.332 & 63.050 & 1.520 & 6.332 & 63.050 & 3.206 & 13.357 & 56.989 \\
\hline ATB & 1.427 & 5.944 & 68.994 & 1.427 & 5.944 & 68.994 & 2.881 & 12.005 & 68.994 \\
\hline
\end{tabular}

Extraction Method: Principal Component Analysis.

Table 5. Total Variance Explained

The factor analysis using the SPSS package version 20 was performed and the data got reduced to five major constructs as shown in Table 6: The standard factor loadings of the items of the constructs were all above 0.5 and hence suitable for analysis.

\begin{tabular}{|l|r|r|r|r|l|}
\hline & \multicolumn{5}{|c|}{ Component } \\
\cline { 2 - 6 } & EDM & JCB & OE & EAB & ATB \\
\hline EDM03 & .824 & & & & \\
EDM02 & .814 & & & & \\
EDM01 & .779 & & & & \\
EDM05 & .746 & & & \\
EDM04 & .732 & .829 & & & \\
JCB04 & & .808 & & & \\
JCB02 & & .802 & & & \\
JCB05 & & .722 & & & \\
JCB03 & & .605 & & & \\
JCB01 & & & .792 & & \\
OE04 & & & & \\
\hline
\end{tabular}




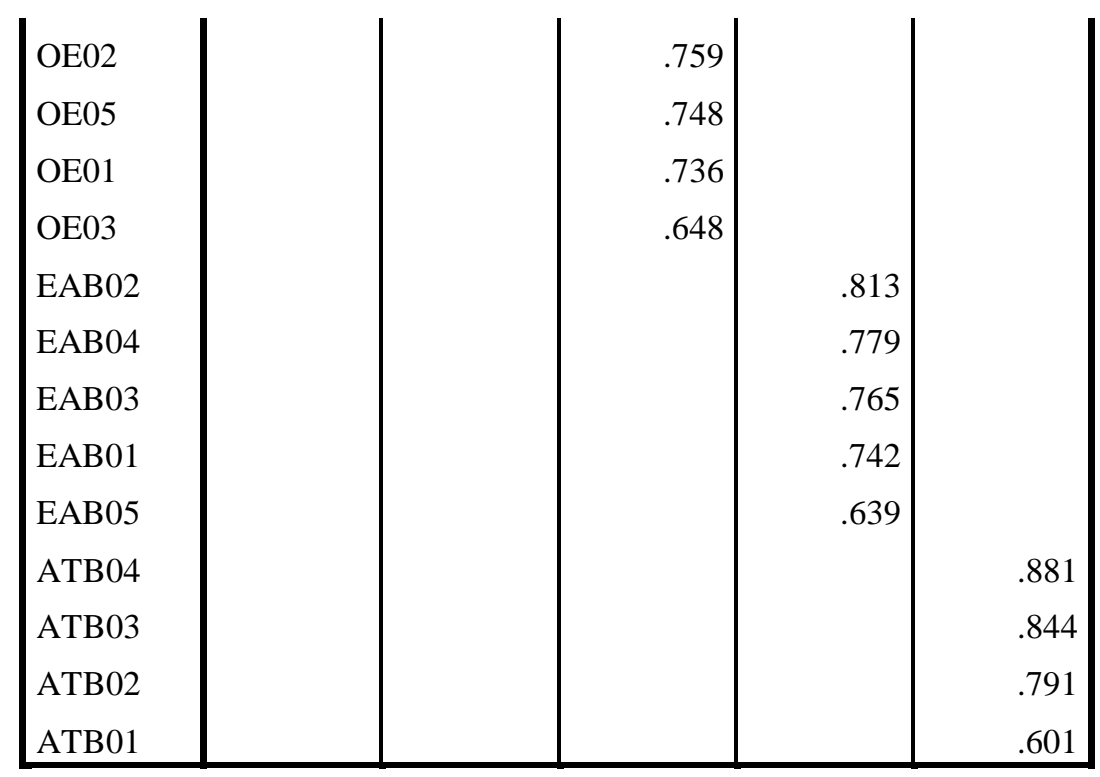

Extraction Method: Principal Component Analysis.

Rotation Method: Varimax with Kaiser Normalization.

a. Rotation converged in 7 iterations.

Table 6: Rotated Component Matrix

\subsection{Construct validity}

In order to understand that the variables possess construct validity, the study has established a face validity and since the scales were adopted from existing literature and previously validated, the variables in the present study confirms the face validity. Further the Cronbach's alpha value of 0.924 suggest its reliability. The factor loadings ranging from 0.601 to 0.881 of the items of the identified variables are also statistically significant, and hence the variables under study passes the construct validity.

\begin{tabular}{|c|c|c|c|c|c|c|c|}
\hline & CR & AVE & EAB & EDM & JCB & OE & ATB \\
\hline EAB & 0.848 & 0.531 & $\mathbf{0 . 7 2 8}$ & & & & \\
\hline EDM & 0.900 & 0.645 & 0.329 & $\mathbf{0 . 8 0 3}$ & & & \\
\hline JCB & 0.880 & 0.598 & 0.293 & 0.574 & $\mathbf{0 . 7 7 3}$ & & \\
\hline OE & 0.869 & 0.571 & 0.605 & 0.474 & 0.488 & $\mathbf{0 . 7 5 5}$ & \\
\hline ATB & 0.889 & 0.675 & 0.248 & 0.506 & 0.497 & 0.392 & $\mathbf{0 . 8 2 2}$ \\
\hline
\end{tabular}

Table 7: Discriminant Validity 
The above Table 7, concludes the discriminant analysis based on the linear combination of the predictor variables which gives the best discrimination of the group. The composite reliability values are greater than the recommended threshold of 0.7 and average variance extracted values are greater than the recommended threshold of 0.5 and hence the convergent validity is assured. Further, it can be inferred from the Table 7, that the square root of AVE values of the construct is greater than the inter-construct correlations supporting the Discriminant validity for the variables.

Fig. 2 The path model

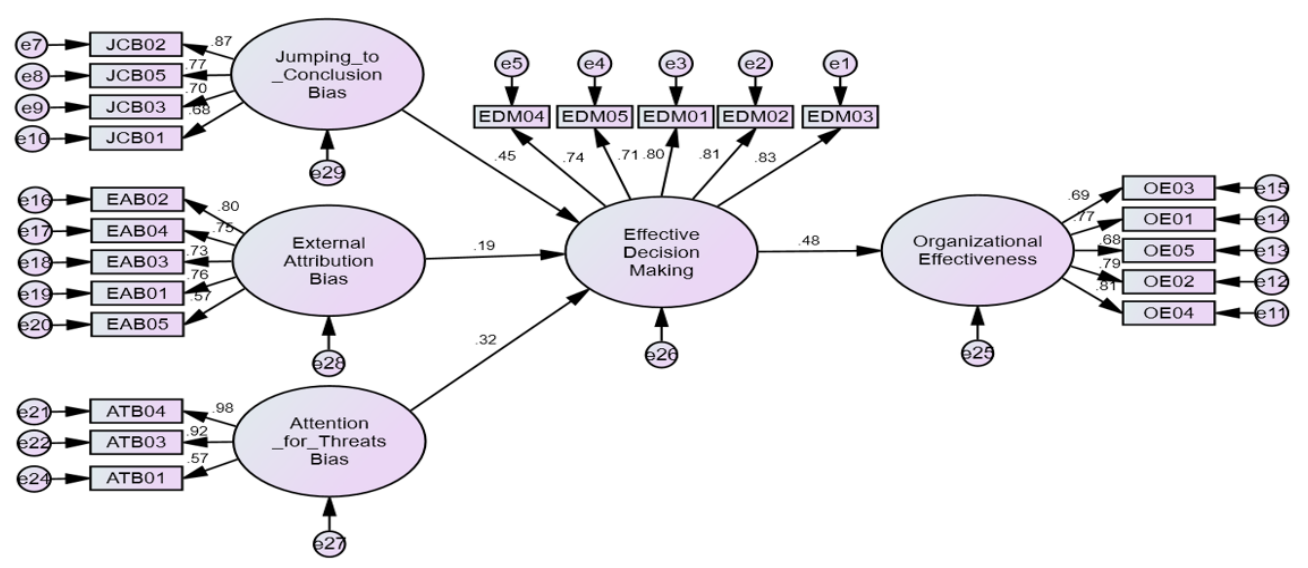

\begin{tabular}{|c|c|c|c|c|c|}
\hline Independent Variables & $\begin{array}{l}\text { Dependent } \\
\text { Variables }\end{array}$ & $\begin{array}{l}\text { SF } \\
\mathbf{L}\end{array}$ & $\begin{array}{c}\text { C.R } \\
\cdot\end{array}$ & $\mathbf{P}$ & $\begin{array}{c}\text { Hypothesis } \\
\text { Testing }\end{array}$ \\
\hline $\begin{array}{l}\text { Jumping to Conclusion } \\
\text { Bias }\end{array}$ & $\begin{array}{l}\text { Effective Decision } \\
\text { Making }\end{array}$ & $\begin{array}{c}0.44 \\
7\end{array}$ & $\begin{array}{c}8.16 \\
9\end{array}$ & $\begin{array}{l}* * \\
*\end{array}$ & Accepted \\
\hline External Attribution Bias & $\begin{array}{l}\text { Effective Decision } \\
\text { Making }\end{array}$ & $\begin{array}{c}0.19 \\
5\end{array}$ & $\begin{array}{c}3.77 \\
1\end{array}$ & $\begin{array}{c}* * \\
*\end{array}$ & Accepted \\
\hline $\begin{array}{l}\text { Attention for Threats } \\
\text { Bias }\end{array}$ & $\begin{array}{l}\text { Effective Decision } \\
\text { Making }\end{array}$ & $\begin{array}{c}0.31 \\
7\end{array}$ & $\begin{array}{c}6.40 \\
8\end{array}$ & $\begin{array}{c}* * \\
*\end{array}$ & Accepted \\
\hline $\begin{array}{l}\text { Effective Decision } \\
\text { Making }\end{array}$ & $\begin{array}{l}\text { Organizational } \\
\text { Effectiveness }\end{array}$ & $\begin{array}{c}0.47 \\
7\end{array}$ & $\begin{array}{c}8.15 \\
2\end{array}$ & $\begin{array}{c}* * \\
*\end{array}$ & Accepted \\
\hline \multicolumn{6}{|c|}{ Squared Multiple Correlations for Organizational Effectiveness $=0.459$} \\
\hline
\end{tabular}

Table 8: Hypothesis Testing

Note: Statistically significant at $* * *=0.001(\mathrm{t}>3.291) ; * *=0.01(\mathrm{t}>2.576) ; \mathrm{NS}=$ Not significant 
The path model above and the table showing the hypothesis testing shows that all the hypothesis proposed in the present study has been accepted with significant t-value and p-values. The model $\mathrm{R} 2$ value is found to be 0.459 suggesting that the model is 46 percent identifiable by the independent variables. This can be improved by including more samples in the study and spreading the study on more inclusive domains.

It is clear from the values in the table 8 that all the beta coefficient values and the t-values along with p-values are found to be significant at 0.001 level and hence supporting the hypotheses of the study. The sample represented in the study supports that Jumping to Conclusion Bias have a positive influence on Effective Decision Making of a firm. Likewise, they also support that External Attribution Bias and Attention for Threats Bias also have a positive influence on Effective Decision Making of a firm. These all variables collectively influence the Organizational Effectiveness of the firm positively.

\section{Discussion}

Kaiser -Meyer-Olkin measure of sampling adequacy was used to test whether the partial correlations between variables are small. Bartlett's test of sphericity was performed to test whether the correlation matrix is an identity matrix, which would specify that the factor model is unsuitable. Factor analysis was used to reduce the number of items and to differentiate structure in the associations between the variables. The results show that the KMO and Bartlett's test support our data set. The KMO value was found to be 0.905 and significant. Bartlett's test of sphericity supported the suitability of using factor analysis to explore the underlying structure of cognitive biases in production, operation and services. A significant result $(\mathrm{p}<0.05)$ specifies matrix is not an identity matrix. An eigen value $>1$ criterion was used to determine the number of dimensions. Varimax rotation was used to obtain suitable results. Factor loadings which are greater than or equal to 0.5 were considered as significant. All the scores of items are shown in Table 6.

The data analysis started with an objective to find out the prevailing relationship and its nature among the variables namely "Jumping to Conclusion Bias (JCB)", "External Attribution Bias (EAB)", "Attention for Threats Bias (ATB)", "Effective Decision Making (EDM)" and "Organizational Effectiveness (OE)". The three biases identified in the literature were hypothesised to have a positive influence on the effective decision making by the firm. This effective decision making in the firm in turn positively influences the overall organizational effectiveness. The path model, which has been developed using AMOS (Version 20) to analyse the relationship, shows that the relationship of all the three cognitive biases on effective decision making have a significant influence. But, the strength of the relationships is more with JCB on $\operatorname{EDM}(\beta=0.447)$ followed by ATB on $\operatorname{EDM}(\beta=0.317)$ and lastly $\operatorname{EAB}$ on $\operatorname{EDM}(\beta=0.195)$. This concludes that the organizational leaders while making or formulating decisions are influenced majorly by the jumping to conclusion biases. The EDM in the organizations in return have a significant influence on the overall organizational effectiveness $(\beta=0.477)$. The overall model explain ability has been found to be 46 percent, which is quite good for a study of the present kind. 


\section{RIDIT Analysis for cognitive biases dimensions}

RIDIT analysis was introduced initially by I. Bross, and has been used in various functional areas of business management and behaviour studies. It is distribution free hence assumption about the distribution of the population under study is not required [62, 63]. Using rigorous mathematical methods, RIDIT score can be derived. RIDIT is a tool made to aid in the analysis of data involving variables that are more than dichotomous classifications and are ordered, but that do not reach the standards of refined measurement systems such as those meeting the criteria for equality interval or ratio scales RIDIT analysis essentially transforms ordinal data to a probability scale. Importantly, RIDIT analysis is closely related to the Wilcoxon rank sum test. The Wilcoxon test statistic and the mean RIDIT are directly related. Fleiss et al also describes how one can test the hypothesis that the mean RIDITS across all groups are equal using a $\chi^{2}$ statistic. In addition, they also describe how one can perform the same test between any group and the reference group [64]. Cognitive biases data during decision making was chosen as reference data set. The frequencies of the responses are shown in Table 9. The RIDIT values of the reference data set for each item were shown in the last row of reference dataset on Table 9.

\begin{tabular}{|c|c|c|c|c|c|c|c|c|}
\hline & $\mathbf{1}$ & $\mathbf{2}$ & $\mathbf{3}$ & $\mathbf{4}$ & $\mathbf{5}$ & $\mathbf{6}$ & $\mathbf{7}$ & \\
\hline JCB01 & 33 & 0 & 77 & 53 & 0 & 111 & 99 & 373 \\
\hline JCB02 & 16 & 0 & 58 & 42 & 0 & 147 & 110 & 373 \\
\hline JCB03 & 24 & 0 & 60 & 56 & 0 & 145 & 88 & 373 \\
\hline JCB04 & 20 & 0 & 52 & 61 & 0 & 142 & 98 & 373 \\
\hline JCB05 & 20 & 0 & 72 & 39 & 0 & 131 & 111 & 373 \\
\hline EAB01 & 2 & 0 & 16 & 36 & 0 & 202 & 117 & 373 \\
\hline EAB02 & 1 & 0 & 13 & 20 & 0 & 176 & 163 & 373 \\
\hline EAB03 & 2 & 0 & 25 & 21 & 0 & 162 & 163 & 373 \\
\hline EAB04 & 3 & 0 & 23 & 19 & 0 & 195 & 133 & 373 \\
\hline EAB05 & 3 & 0 & 21 & 40 & 0 & 190 & 119 & 373 \\
\hline ATB01 & 4 & 0 & 69 & 50 & 8 & 165 & 77 & 373 \\
\hline ATB02 & 11 & 0 & 53 & 57 & 0 & 162 & 90 & 373 \\
\hline ATB03 & 19 & 0 & 57 & 47 & 0 & 86 & 164 & 373 \\
\hline ATB04 & 19 & 0 & 58 & 46 & 0 & 153 & 97 & 373 \\
\hline Freq & 177 & 0 & 654 & 587 & 8 & 2167 & 1629 & 522 \\
\hline 1/2 & 88.5 & 0 & 327 & 293.5 & 4 & 1083.5 & 814.5 & \\
\hline Freq & 88.5 & 177 & 504 & 1124.5 & 1422 & 2509.5 & 4407.5 & \\
\hline ri & 0.01694 & 0.03389 & 0.09651 & 0.21533 & 0.27230 & 0.48056 & 0.84402 & \\
\hline
\end{tabular}

Table 9: RIDIT values for the reference dataset 
Weights that are summed to derive RIDIT values and the priority rankings associated with those RIDIT scores are shown in Table 10.

\begin{tabular}{|c|c|c|c|c|c|c|c|c|c|c|c|}
\hline & 1 & 2 & 3 & 4 & 5 & 6 & 7 & $\rho i$ & $\begin{array}{l}\text { Lower } \\
\text { bound }\end{array}$ & $\begin{array}{l}\text { Upper } \\
\text { bound }\end{array}$ & $\begin{array}{l}\text { Priority } \\
\text { Ranking }\end{array}$ \\
\hline $\begin{array}{l}\text { JCB } \\
01\end{array}$ & $\begin{array}{r}0.00 \\
15\end{array}$ & $\begin{array}{r}0.00 \\
00\end{array}$ & $\begin{array}{r}0.019 \\
9\end{array}$ & $\begin{array}{r}0.030 \\
6\end{array}$ & $\begin{array}{r}0.000 \\
0\end{array}$ & $\begin{array}{r}0.143 \\
0\end{array}$ & $\begin{array}{r}0.224 \\
0\end{array}$ & $\begin{array}{r}0.419 \\
048\end{array}$ & $\begin{array}{r}0.384 \\
39658 \\
4\end{array}$ & $\begin{array}{r}0.453 \\
6992 \\
01\end{array}$ & 14 \\
\hline $\begin{array}{l}\text { JCB } \\
02 \\
\end{array}$ & $\begin{array}{r}0.00 \\
07 \\
\end{array}$ & $\begin{array}{r}0.00 \\
00 \\
\end{array}$ & $\begin{array}{r}0.015 \\
0 \\
\end{array}$ & $\begin{array}{r}0.024 \\
2 \\
\end{array}$ & $\begin{array}{r}0.000 \\
0 \\
\end{array}$ & $\begin{array}{r}0.189 \\
4 \\
\end{array}$ & $\begin{array}{r}0.248 \\
9 \\
\end{array}$ & $\begin{array}{r}0.478 \\
281 \\
\end{array}$ & $\begin{array}{r}0.437 \\
18119 \\
1 \\
\end{array}$ & $\begin{array}{r}0.519 \\
3807 \\
04 \\
\end{array}$ & 7 \\
\hline $\begin{array}{l}\text { JCB } \\
03\end{array}$ & $\begin{array}{r}0.00 \\
11 \\
\end{array}$ & $\begin{array}{r}0.00 \\
00 \\
\end{array}$ & $\begin{array}{r}0.015 \\
5 \\
\end{array}$ & $\begin{array}{r}0.032 \\
3 \\
\end{array}$ & $\begin{array}{r}0.000 \\
0 \\
\end{array}$ & $\begin{array}{r}0.186 \\
8 \\
\end{array}$ & $\begin{array}{r}0.199 \\
1 \\
\end{array}$ & $\begin{array}{r}0.434 \\
886 \\
\end{array}$ & $\begin{array}{r}0.399 \\
52673 \\
2 \\
\end{array}$ & $\begin{array}{r}0.470 \\
2452 \\
07 \\
\end{array}$ & 13 \\
\hline $\begin{array}{l}\text { JCB } \\
04\end{array}$ & $\begin{array}{r}0.00 \\
09\end{array}$ & $\begin{array}{r}0.00 \\
00\end{array}$ & $\begin{array}{r}0.013 \\
5\end{array}$ & $\begin{array}{r}0.035 \\
2\end{array}$ & $\begin{array}{r}0.000 \\
0\end{array}$ & $\begin{array}{r}0.182 \\
9\end{array}$ & $\begin{array}{r}0.221 \\
8\end{array}$ & $\begin{array}{r}0.454 \\
284\end{array}$ & $\begin{array}{r}0.416 \\
89492\end{array}$ & $\begin{array}{r}0.491 \\
6724 \\
63\end{array}$ & 11 \\
\hline $\begin{array}{l}\text { JCB } \\
05\end{array}$ & $\begin{array}{r}0.00 \\
09\end{array}$ & $\begin{array}{r}0.00 \\
00\end{array}$ & $\begin{array}{r}0.018 \\
6\end{array}$ & $\begin{array}{r}0.022 \\
5\end{array}$ & $\begin{array}{r}0.000 \\
0\end{array}$ & $\begin{array}{r}0.168 \\
8\end{array}$ & $\begin{array}{r}0.251 \\
2\end{array}$ & $\begin{array}{r}0.462 \\
002\end{array}$ & $\begin{array}{r}0.422 \\
17573 \\
9\end{array}$ & $\begin{array}{r}0.501 \\
8285\end{array}$ & 8 \\
\hline $\begin{array}{l}\text { EAB } \\
01\end{array}$ & $\begin{array}{r}0.00 \\
01 \\
\end{array}$ & $\begin{array}{r}0.00 \\
00 \\
\end{array}$ & $\begin{array}{r}0.004 \\
1 \\
\end{array}$ & $\begin{array}{r}0.020 \\
8 \\
\end{array}$ & $\begin{array}{r}0.000 \\
0 \\
\end{array}$ & $\begin{array}{r}0.260 \\
3 \\
\end{array}$ & $\begin{array}{r}0.264 \\
7 \\
\end{array}$ & $\begin{array}{r}0.550 \\
013 \\
\end{array}$ & $\begin{array}{r}0.500 \\
67453 \\
2 \\
\end{array}$ & $\begin{array}{r}0.599 \\
3523 \\
7 \\
\end{array}$ & 4 \\
\hline $\begin{array}{l}\text { EAB } \\
02\end{array}$ & $\begin{array}{r}0.00 \\
00 \\
\end{array}$ & $\begin{array}{r}0.00 \\
00 \\
\end{array}$ & $\begin{array}{r}0.003 \\
4\end{array}$ & $\begin{array}{r}0.011 \\
5\end{array}$ & $\begin{array}{r}0.000 \\
0 \\
\end{array}$ & $\begin{array}{r}0.226 \\
8 \\
\end{array}$ & $\begin{array}{r}0.368 \\
8\end{array}$ & $\begin{array}{r}0.610 \\
546\end{array}$ & $\begin{array}{r}0.551 \\
88870 \\
6\end{array}$ & $\begin{array}{r}0.669 \\
2031 \\
27 \\
\end{array}$ & 1 \\
\hline $\begin{array}{l}\text { EAB } \\
03\end{array}$ & $\begin{array}{r}0.00 \\
01\end{array}$ & $\begin{array}{r}0.00 \\
00\end{array}$ & $\begin{array}{r}0.006 \\
5\end{array}$ & $\begin{array}{r}0.012 \\
1\end{array}$ & $\begin{array}{r}0.000 \\
0\end{array}$ & $\begin{array}{r}0.208 \\
7\end{array}$ & $\begin{array}{r}0.368 \\
8\end{array}$ & $\begin{array}{r}0.596 \\
236\end{array}$ & $\begin{array}{r}0.538 \\
75760 \\
6\end{array}$ & $\begin{array}{r}0.653 \\
7153 \\
61\end{array}$ & 2 \\
\hline $\begin{array}{l}\text { EAB } \\
04\end{array}$ & $\begin{array}{r}0.00 \\
01\end{array}$ & $\begin{array}{r}0.00 \\
00\end{array}$ & $\begin{array}{r}0.006 \\
0\end{array}$ & $\begin{array}{r}0.011 \\
0\end{array}$ & $\begin{array}{r}0.000 \\
0\end{array}$ & $\begin{array}{r}0.251 \\
2\end{array}$ & $\begin{array}{r}0.301 \\
0\end{array}$ & $\begin{array}{r}0.569 \\
242\end{array}$ & $\begin{array}{r}0.516 \\
75906 \\
2\end{array}$ & $\begin{array}{r}0.621 \\
7249 \\
55\end{array}$ & 3 \\
\hline $\begin{array}{l}\text { EAB } \\
05\end{array}$ & $\begin{array}{r}0.00 \\
01\end{array}$ & $\begin{array}{r}0.00 \\
00\end{array}$ & $\begin{array}{r}0.005 \\
4\end{array}$ & $\begin{array}{r}0.023 \\
1\end{array}$ & $\begin{array}{r}0.000 \\
0\end{array}$ & $\begin{array}{r}0.244 \\
8\end{array}$ & $\begin{array}{r}0.269 \\
3\end{array}$ & $\begin{array}{r}0.542 \\
727\end{array}$ & $\begin{array}{r}0.494 \\
47460 \\
5\end{array}$ & $\begin{array}{r}0.590 \\
9794 \\
91\end{array}$ & 5 \\
\hline $\begin{array}{l}\text { ATB } \\
01\end{array}$ & $\begin{array}{r}0.00 \\
02\end{array}$ & $\begin{array}{r}0.00 \\
00\end{array}$ & $\begin{array}{r}0.017 \\
9\end{array}$ & $\begin{array}{r}0.028 \\
9\end{array}$ & $\begin{array}{r}0.005 \\
8\end{array}$ & $\begin{array}{r}0.212 \\
6\end{array}$ & $\begin{array}{r}0.174 \\
2\end{array}$ & $\begin{array}{r}0.439 \\
559\end{array}$ & $\begin{array}{r}0.404 \\
08675 \\
7\end{array}$ & $\begin{array}{r}0.475 \\
0315 \\
95\end{array}$ & 12 \\
\hline $\begin{array}{l}\text { ATB } \\
02\end{array}$ & $\begin{array}{r}0.00 \\
05\end{array}$ & $\begin{array}{r}0.00 \\
00\end{array}$ & $\begin{array}{r}0.013 \\
7\end{array}$ & $\begin{array}{r}0.032 \\
9\end{array}$ & $\begin{array}{r}0.000 \\
0\end{array}$ & $\begin{array}{r}0.208 \\
7\end{array}$ & $\begin{array}{r}0.203 \\
7\end{array}$ & $\begin{array}{r}0.459 \\
489\end{array}$ & $\begin{array}{r}0.421 \\
56970 \\
3\end{array}$ & $\begin{array}{r}0.497 \\
4088 \\
81\end{array}$ & 9 \\
\hline $\begin{array}{l}\text { ATB } \\
03\end{array}$ & $\begin{array}{r}0.00 \\
09\end{array}$ & $\begin{array}{r}0.00 \\
00\end{array}$ & $\begin{array}{r}0.014 \\
7\end{array}$ & $\begin{array}{r}0.027 \\
1\end{array}$ & $\begin{array}{r}0.000 \\
0\end{array}$ & $\begin{array}{r}0.110 \\
8\end{array}$ & $\begin{array}{r}0.371 \\
1\end{array}$ & $\begin{array}{r}0.524 \\
646\end{array}$ & $\begin{array}{r}0.471 \\
17919 \\
1\end{array}$ & $\begin{array}{r}0.578 \\
1121 \\
66\end{array}$ & 6 \\
\hline $\begin{array}{l}\text { ATB } \\
04\end{array}$ & $\begin{array}{r}0.00 \\
09 \\
\end{array}$ & $\begin{array}{r}0.00 \\
00 \\
\end{array}$ & $\begin{array}{r}0.015 \\
0 \\
\end{array}$ & $\begin{array}{r}0.026 \\
6 \\
\end{array}$ & $\begin{array}{r}0.000 \\
0 \\
\end{array}$ & $\begin{array}{r}0.197 \\
1 \\
\end{array}$ & $\begin{array}{r}0.219 \\
5 \\
\end{array}$ & $\begin{array}{r}0.459 \\
04 \\
\end{array}$ & $\begin{array}{r}0.420 \\
54577 \\
8 \\
\end{array}$ & $\begin{array}{r}0.497 \\
5348 \\
73 \\
\end{array}$ & 10 \\
\hline
\end{tabular}

Table 10: Computation of the RIDIT values for the comparison datasets and prioritization

Taking the first row in Table 10 which has the variable JCB1, the value of 0.0015 is derived from Table 9 by multiplying the frequency of 33 (from the row marked JCB1 in Table 9) by 
the reference group RIDIT values of 0.016948 (found in the bottom row of Table 9) and then dividing by the $\mathrm{n}$ of 373 (from the last column of Table 9). The weights from the five columns are then summed to get RIDIT scores. Mathematically the average RIDIT value will be 0.5 . Those items with relatively more response of 7 and 6 will tend to have a RIDIT value of greater than 0.5 . Those items with relatively more responses of 2 and 1 will have a RIDIT value of less than 0.5. Consequently, the higher the RIDIT value is, the higher priority the sample places on the item will be. We assign priority rankings to the items with the highest priority going to the highest RIDIT value. The Kruskal-Wallis W was calculated to be 236.7804 . Because the W (236.7804) is significantly greater than $\mathrm{x} 2(14-1)=19.6751$, it can be inferred that the opinions about the scale items among the respondents are statistically different. This test is a rank-based nonparametric test that can be used to check if there are statistically significant differences between two or more groups of an independent variable. It does not require the data to be normal, but instead uses the rank of the data values for the analysis.

From the RIDIT ranking analysis (Table 10), it was found that out of all the cognitive biases dimensions, the dimensions of external attribution bias are given utmost priority by the respondents followed by the dimensions of jumping to conclusion bias, whereas the least priority was assigned to the dimensions of attention for threats bias. The results of the RIDIT priority index shows that external attribution bias is most significant dimension among the cognitive biases proposed in the present study. Among the EAB dimensions, the item stating 'it is not my fault when things go wrong in my life' (EAB02) has been given top priority by the respondents followed by item stating 'people don't give me a chance to do well' (EAB03) and item stating 'I don't change my way of thinking easily'(EAB04). Hence, managers need to concentrate more on reducing external attribution bias in order to improve the quality of decision making. This can be done by facilitating motivations sessions for the employees. The other dimensions and their relative ranking are also found to be more or less symmetrical. This means the groupings of the variables being done by factor analysis under each construct in a way justifies their rankings being done by RIDIT analysis. The overall ranking of the cognitive biases dimensions was shown in Table 10.

\section{Limitations and suggestions for future study}

There are some limitations in the study. This research focussed on the factors of cognitive biases of the decision-makers. Making decisions effectively is a complex procedure. Effective decision making may not be influenced only by cognitive biases. It can be influenced by various other factors such as the personality of decision-makers, social network, environment etc. In this study, only four cognitive biases were taken for analysing their impact on decision making process. Apart from those biases there exist many other cognitive biases which may impact the effective decision-making process. Hence these limitations can be considered as a gap in the future research.

\section{Conclusion}

The present study attempted to examine the impact of cognitive biases on effective decisionmaking process and impact of effective decision-making process on overall organizational 
effectiveness. The study was concentrated on manufacturing units of Kerala state of India for making the analysis. While it was discussed and inferred in the literature review that the cognitive biases of all kinds do have a significant influence on the decision-making process at all levels of the organization, it has been empirically accepted and concluded in the present study also. The present study concludes that at every level of decision-making process in an organization and in particular, manufacturing units, biases do occur and which influences the outcome of the decision resulting in a deviation from the actual supposed outcome. This in return have a radical impact on the overall organizational effectiveness in achieving its short term as well as long term goals.

The study also strongly argue that the organizational effectiveness is highly reactive to the decision-making process in an organization because the decisions taken at various levels combine together and move towards the goal achievement of the organization. So, this becomes very important to have a proper decision-making process for a flaw less implementation of the decisions which constructively work toward improving the organizational effectiveness. Further, the study also argue that the decisions are backed by and influenced by cognitive biases at most of the levels of an organization. These biases are jumping to conclusion, belief inflexibility, attention for threat and external attribution. These biases in particular have a significant influence on the decision-making process in the manufacturing units considered under the present study.

Hence, the present study finally concludes that any organization and particularly, manufacturing units need to focus on taking measures for reducing and eliminating the biases influencing the decision-making process for improving the organizational effectiveness in the long run and for its sustainability. The study recommends CEOs and top-level managers to concentrate on identifying the cognitive biases and find various de-biasing techniques to eliminate those biases during decision making which in turn will increase organizational effectiveness.

\section{References}

[1] Macola, G., 2016. The gun in central Africa: a history of technology and politics. Ohio University Press.

[2] Ehrlinger, J., Readinger, W.O. and Kim, B., 2016. Decision-making and cognitive biases. [3] Negulescu, O. and Doval, E., 2014. The quality of decision-making process related to organizations' effectiveness. Procedia Economics and Finance, 15, pp.858-863.

[4] Georgopoulos, B.S. and Tannenbaum, A.S., 1957. A study of organizational effectiveness. American Sociological Review, 22(5), pp.534-540.

[5] Thorndike, R.L., 1949. Personnel selection; test and measurement techniques.

[6] Kahn, R.L., 1956. The prediction of productivity. Journal of Social Issues, 12(2), pp.4149.

[7] Cameron, K.S. and Whetten, D.A., 1983. Organizational effectiveness: one model or several? In Organizational Effectiveness (pp. 1-24). Academic Press.

[8] Roy, M.H. and Dugal, S.S., 2005. Using employee gainsharing plans to improve organizational effectiveness. Benchmarking: An International Journal, 12(3), pp.250-259.

[9] Katz, D. and Kahn, R.L., 1966. The Social Psychology of Organizations. Wiley. 
[10] Hannan, M.T. and Freeman, J., 1977. The population ecology of organizations. American journal of sociology, 82(5), pp.929-964.

[11] Mott, P.E., 1972. The characteristics of effective organizations. New York: Harper \& Row.

[12] Fallon, T. and Brinkerhoff, R.O., 1996. Framework for organizational effectiveness. In American Society for Training and Development International Conference.

[13] Balduck, A.L. and Buelens, M., 2008. A two-level competing values approach to measure non-profit organizational effectiveness. Ghent University: Vlerick Leuven Gent Management School.

[14] Angle, H.L. and Perry, J.L., 1981. An empirical assessment of organizational commitment and organizational effectiveness. Administrative science quarterly, pp.1-14.

[15] Koyuncu, M., Burke, R.J. and Fiksenbaum, L., 2006. Work engagement among women managers and professionals in a Turkish bank: Potential antecedents and consequences. Equal Opportunities International, 25(4), pp.299-310.

[16] Sanderson, C. and Gruen, R., 2006. Analytical models for decision-making. McGrawHill Education (UK).

[17] Blenko, M. and Davis-Peccoud, J., 2011. Great decisions-not a solo performance.

[18] DuBrin, A.J., 2015. Leadership: Research findings, practice, and skills. Nelson Education.

[19] Schermerhorn, J. R., Hunt, J. G., \& Osborn, R. N. (2011). Organizational behavior (11th ed.). New York, NY: Wiley.

[20] McGregor, L., 2001. Improving the quality and speed of decision making. Journal of change management, 2(4), pp.344-356.

[21] Flüeler, T. and Blowers, A., 2007. Quality of decision-making processes. Decision making processes in radioactive waste governance-Insights and recommendations, COWAM, Digital version. http://www. cowam. com/IMG/pdf_cowam2_WP3_v2. pdf. Accessed May, 8, p.2014.

[22] Dezfuli, H., Maggio, G. and Everett, C., 2010. Risk-informed decision making: Application to technology development alternative selection.

[23] Ytanyi, O., Ewurum, U.J.F., Upere, W. I., 2012, Evaluation of decision-making criteria with special references to quantitative and qualitative paradigms, African Journal of Business Management, Vol.6 (44), pp.11110-1117.

[24] Grapentine, L., Anderson, J., Boyd, D., Burton, G.A., DeBarros, C., Johnson, G., Marvin, C., Milani, D., Painter, S., Pascoe, T. and Reynoldson, T., 2002. A decision-making framework for sediment assessment developed for the Great Lakes. Human and Ecological Risk Assessment, 8(7), pp.1641-1655.

[25] Dye, R., Sibony, O. and Viguerie, S.P., 2009. Strategic planning: Three tips for 2009. The McKinsey Quarterly, 9(1).

[26] Nazeri, A., Javanmard, H., Rashidi, S. and Tohidi, A.A., 2011. The Effect of Quality Management and Participative Decision-Making on Individual Performance. In International Conference on Information Communication and Management IPCSIT (Vol. 16, pp. 83-87).

[27] D'Avino, M., Correale, M.M. and Schiraldi, M.M., 2013. No news, good news: positive impacts of delayed information in MRP. International Journal of Management and Decision Making, 12(3), pp.312-334.

[28] Driver, M.J., Brousseau, K.R. and Hunsaker, P.L., 1998. The dynamic decision maker: Five decision styles for executive and business success. IUniverse. 
[29] Raghunathan, S., 1999. Impact of information quality and decision-maker quality on decision quality: a theoretical model and simulation analysis. Decision Support Systems, 26(4), pp.275-286.

[30] Johnson, M.R. and McCarthy, I.P., 2014. Product recovery decisions within the context of Extended Producer Responsibility. Journal of Engineering and Technology Management, 34, pp.9-28.

[31] Blenko, M. and Davis-Peccoud, J., 2011. Great decisions-not a solo performance.

[32] Drucker, P. F. (2009). The effective executive. New York, NY: HarperCollins

[33] J. R. Schermerharm, J. G. Hunt, R. N. Osborn, Organizational Behaviour (11th ed.), New York, NY: Wiley, 2011.

[34] UK. McGregor, R., 2010. The Party: the secret world of China's communist rulers. Penguin UK.

[35] Flüeler, T. and Blowers, A., 2007. Quality of decision-making processes. Decision making processes in radioactive waste governance-Insights and recommendations, COWAM, Digital version. http://www. cowam. com/IMG/pdf_cowam2_WP3_v2. pdf. Accessed May, 8, p.2014.

[36] Grapentine, L., Anderson, J., Boyd, D., Burton, G.A., DeBarros, C., Johnson, G., Marvin, C., Milani, D., Painter, S., Pascoe, T. and Reynoldson, T., 2002. A decision-making framework for sediment assessment developed for the Great Lakes. Human and Ecological Risk Assessment, 8(7), pp.1641-1655.

[37] Nazeri, A., Javanmard, H., Rashidi, S. and Tohidi, A.A., 2011. The Effect of Quality Management and Participative Decision-Making on Individual Performance. In International Conference on Information Communication and Management IPCSIT (Vol. 16, pp. 83-87).

[38] Lockton, D., 2012. Cognitive biases, heuristics and decision-making in design for behaviour change.

[39] Gigerenzer, G. and Todd, P.M., 1999. Simple heuristics that make us smart. Evolution and Cognition (Paper.

[40] Edwards, W. and Von Winterfeldt, D., 1985. Cognitive illusions and their implications for the law. S. Cal. L. Rev., 59, p.225.

[41] Kahneman, D. and Tversky, A., 1982. On the study of statistical intuitions. Cognition, 11(2), pp.123-141.

[42] Lyles, M.A. and Thomas, H., 1988. Strategic problem formulation: biases and assumptions embedded in alternative decision-making models. Journal of Management Studies, 25(2), pp.131-145.

[43] Zajac, E.J. and Bazerman, M.H., 1991. Blind spots in strategic decision-making: The case of competitor analysis. Academy of Management Review, 16(1), pp.37-56.

[44] Hastie, R. and Dawes, R.M., Rational choice in an uncertain world: The psychology of judgment and decision making. 2001.

[45] Loewenstein, G., 1996. Out of control: Visceral influences on behavior. Organizational behavior and human decision processes, 65(3), pp.272-292.

[46] Hamilton, C., 2011. Cengage advantage books: Essentials of public speaking. Cengage Learning.

[47] O'Sullivan, J.R., 2003. Some Thoughts on Proposed Revisions to the Organizational Guidelines. Ohio St. J. Crim. L., 1, p.487.

[48] Holli, B.B., Calabrese, R.J. and Maillet, J.O.S., 2003. Communication and education skills for dietetics professionals. XYZ editeur/XYZ Publishing. 
[49] Kaiser, K.M., 1996. European bankruptcy laws: Implications for corporations facing financial distress. Financial Management, pp.67-85.

[50] Groopman, J., 2008. How doctors think. Houghton Mifflin Harcourt.

[51] Zhu, C., Sun, X. and So, S.H.W., 2018. Associations between belief inflexibility and dimensions of delusions: A meta-analytic review of two approaches to assessing belief flexibility. British Journal of Clinical Psychology, 57(1), pp.59-81.

[52] Bar-Haim, Y., Lamy, D., Pergamin, L., Bakermans-Kranenburg, M.J. and Van Ijzendoorn, M.H., 2007. Threat-related attentional bias in anxious and non-anxious individuals: a meta-analytic study. Psychological bulletin, 133(1), p.1.

[53] Lonigan, C.J., Vasey, M.W., Phillips, B.M. and Hazen, R.A., 2004. Temperament, anxiety, and the processing of threat-relevant stimuli. Journal of Clinical Child and Adolescent Psychology, 33(1), pp.8-20.

[54] Baron, J., 2008. Thinking and Deciding-Cambridge University Press. New York

[55] Pfabigan, D.M. and Tran, U.S., 2015. Behavioral and physiological bases of attentional biases: paradigms, participants, and stimuli. Frontiers in psychology, 6, p.686.

[56] Himmelfarb, S. and Eagly, A.H., 1974. Readings in attitude change. John Wiley \& Sons. [57] Seligman, M.E., Abramson, L.Y., Semmel, A. and Von Baeyer, C., 1979. Depressive attributional style. Journal of abnormal psychology, 88(3), p.242.

[58] Funder, D.C., 1987. Errors and mistakes: Evaluating the accuracy of social judgment. Psychological bulletin, 101(1), p.75.

[59] Heider, F., 1958. Consciousness, the perceptual world, and communications with others. Person perception and interpersonal behavior, pp.27-32.

[60] van der Gaag, M., Schütz, C., ten Napel, A., Landa, Y., Delespaul, P., Bak, M., Tschacher, W. and De Hert, M., 2013. Development of the Davos assessment of cognitive biases scale (DACOBS). Schizophrenia Research, 144(1-3), pp.63-71.

[61] French, D.J., West, R.J., Elander, J. and WILDING, J.M., 1993. Decision-making style, driving style, and self-reported involvement in road traffic accidents. Ergonomics, 36(6), pp.627-644.

[62] F. Hair Jr, J., Sarstedt, M., Hopkins, L. and G. Kuppelwieser, V., 2014. Partial least squares structural equation modelling (PLS-SEM) An emerging tool in business research. European Business Review, 26(2), pp.106-121.

[63] Bross, I.D., 1958. How to use RIDIT analysis. Biometrics, pp.18-38.

[64] Fleiss, J.L., Levin, B. and Paik, M.C., 2013. Statistical methods for rates and proportions. John Wiley \& Sons. 